Papers presented at the "XX. Days of Animal Physiology" in honour of Professor Antonín Holub

\title{
Cellulolytic Bacteria in Human Gut and Irritable Bowel Syndrome
}

\author{
J. KOPEČNÝ, J. ŠIMU゚NEK
}

Institute of Animal Physiology and Genetics, Czech Academy of Sciences, Prague, Czech Republic

Received July 22, 2002

Accepted November 18, 2002

\section{Abstract}

Kopečný J., J. Šimůnek: Cellulolytic Bcteria in Human Gut and Irritable Bowel Syndrome, Acta Vet. Brno 2002, 71: 421-427.

Irritable bowel syndrome (IBS) represents one of three major forms of chronic inflammatory bowel disease. The aim of the present study was to investigate the composition and metabolic activities of faecal flora in IBS patients that may take part in initiation and/or maintaining of the disease state. All experiments were designed for three groups of stool donors: healthy individuals, patients with irritable bowel syndrome (IBS) diagnosis before and after treatment by prebiotic preparation Hylak Tropfen Forte.

The faecal short chain fatty acid (SCFA) profile of IBS patients was characterized by lower concentration of total SCFA, acetate and propionate $(88.15,60.16$ and $18.06 \mathrm{mmol} / \mathrm{l}$, resp.) and by higher concentration of butyrate $(9.93 \mathrm{mmol} / \mathrm{l})$. After treatment with Hylak Tropfen Forte, the concentration of total SCFA, acetate and propionate increased (100.66, 75.60 and 18.21 $\mathrm{mmol} / \mathrm{l}$, resp.). On the other hand the butyrate concentration decreased (from 9.93 to 6.84 mmol/l). SCFA concentrations in the control group samples for total SCFA, acetate and propionate were as follows: $108.95,73.26,26.08 \mathrm{mmol} / \mathrm{l}$.

Patients with irritable bowel syndrome diagnosis showed remarkable changes in faecal bacterial population. There were increased numbers of facultative anaerobes and sulphate reducing bacteria. Significantly lower were the counts of cellulolytic bacteria. Total counts of pectinolytic, proteolytic, lactate utilizing and lipolytic bacteria were not significantly different. After treatment with Hylak Tropfen Forte the counts of facultative anaerobes and sulphate reducing bacteria decreased and proportion of cellulolytic bacteria increased significantly and were closer to numbers in faecal samples from healthy persons. This activity could be therefore a possible indicator of irritable bowel syndrome.

Faecal bacteria from all three groups of donors were tested for their ability to degrade cellulose, pectin and starch in vitro. Starch degradation was significantly depressed in IBS patients and lower concentrations of acetate, propionate and butyrate were found. Pectin degradation in vitro followed a similar pattern. No degradation of cellulose was found. After treatment with Hylak Tropfen Forte bacterial degradation of these polysaccharides increased but not to the levels of the control group.

Anaerobic bacteria, colon, fibrolytic, SCFA, prebiotic

The irritable bowel syndrome (IBS) refers to a symptom complex arising from the interactions among the digestive tract, the psyche and luminal factors. The gastrointestinal symptoms include abdominal pain related to bowel movements, distension, altered bowel habit, passage of mucus, and sense of incomplete evacuation after defecation (Camilleri and Prather 1992). The IBS may be associated with an abnormal gut microflora (King and Hunter 1998). Composition and activity of microflora as well as environmental conditions in the colonic lumen affect the short chain fatty acids (SCFA) production playing key role in establishing a balanced ecosystem in the colon. Certain intestinal diseases may lead to specific patterns of SCFAs (Treem et al. 1996). It was suggested that butyrate deficiency might be involved in the pathogenesis of ulcerative colitis (Scheppach et al. 1992). Butyrate uptake in the colonic mucosal cells of patients with ulcerative colitis was reduced when compared

Address for correspondence:

Ing. Jan Kopečný, DrSc.

Institute of Animal Physiology and Genetics CAS

Czech Republic
Phone: +420267090502

Fax: +420 267090500

ecny@iapg.cas.cz

http://www.vfu.cz/acta-vet/actavet.htm 
with controls and it was suggested that failure to utilize butyrate could be an important factor in the etiology of irritable bowel syndrome (Roediger 1980). Conversely, concentrations of faecal butyrate in patients with diarrhea-predominant irritable bowel syndrome were increased (Treem at al. 1996).

The aim of present study was an investigation of microbial community of anaerobic bacteria in feces of patients with irritable bowel syndrome and healthy persons. Experiments were designed to follow changes in production and proportions of microbial fermentation end products (SCFA and ammonia). The possibility to modulate the fermentation pattern in patients with irritable bowel syndrome diagnosis by Hylak Tropfen Forte-forte therapy was also studied.

\section{Materials and Methods}

Subjects

Five healthy subjects served as a control group. Another sixteen persons with diagnosis of irritable bowel syndrome were included in this study. In the latter group, stool samples were taken before and after 10 days of treatment with Hylak Tropfen Forte (Merckle, Austria) in doses of 40 drops three times per day. There were no restrictions in diets of any persons tested.

\section{Collection and processing of faecal samples}

Portions of freshly voided faecal samples about 10-15 g were closed in sterile Petri dishes and immediately placed into anaerostat and transported under anaerobic atmosphere composed of carbon dioxide and hydrogen (Gas Generating Anaerobic System, Oxoid). Faecal samples (5 g) were homogenized in 10 volumes (w/v) of physiological saline $(9 \mathrm{~g} / \mathrm{l}$ of $\mathrm{NaCl})$ under steam of nitrogen for ammonia and short chain fatty acids (SCFA) determination.

Microbiological tests

Sub-samples of faeces $(1 \mathrm{~g})$ were transferred to a pre-weighed Hungate tube containing $9 \mathrm{ml}$ of anaerobic dilution solution (Bryant and Burkey 1953). A serial dilution was carried out down to 10-10. Duplicate samples of 103-10-10 dilutions were plated on Petri dishes with modified anaerobic agar medium M-10 supplied with $10 \%$ (v/v) of rumen fluid. Pectin, linseed oil (Sigma), casein vitamin free (Fluka) and carboxymethylcellulose (CMC) sodium salt (Fluka) were added in the amount of $0.4 \mathrm{~g} / 100 \mathrm{ml}$. Sodium lactate and sodium sulphate were added to final concentration $100 \mathrm{mM}$. Agars used for cultivation of anaerobes were placed into anaerobic glove box and cultivated at $39{ }^{\circ} \mathrm{C}$ for $48 \mathrm{~h}$ (pectin, sodium lactate, sodium sulphate, lipids) and for $72 \mathrm{~h}$ (carboxymethylcellulose). Bacterial counts (CFU - colony forming units) of selected groups of anaerobic bacteria (pectinolytic, proteolytic, lipolytic, cellulolytic, lactate utilizing and sulphate reducing) were estimated. The CMC agar plates were then stained with Congo Red using the method of Teather and Wood (1982). Clear zones around colonies possessing cellulases indicated cellulolytic activity. Facultative anaerobic bacteria were counted after $48 \mathrm{~h}$ of incubation on SS agar and Purple Serum Agar (Oxoid) at $39{ }^{\circ} \mathrm{C}$ under aerobic atmosphere. The numbers of CFU were expressed per 1 gram of dry faecal matter.

In vitro incubations of faeces

Faecal samples $(20 \mathrm{~g})$ were homogenized in $200 \mathrm{ml}$ of anaerobically prepared physiological saline $(9 \mathrm{~g}$ sodium chloride/l) solution $(4 \mathrm{~g} / \mathrm{l}$ of cysteine under a stream of oxygen-free gas mixture: nitrogen, carbon dioxide and hydrogen: 70, 25 and $5 \%$ respectively).

The portions of faecal homogenate $(5 \mathrm{ml})$ were dispensed into serum bottles with $45 \mathrm{ml}$ of McDougall buffer, which contained minerals, vitamins and trace elements (Kopečný et al. 1981). Starch, pectin or carboxymethylcellulose (final concentration $4 \mathrm{~g} / \mathrm{l}$ ) were used as carbon sources. Incubations were carried out at $39{ }^{\circ} \mathrm{C}$ for $24 \mathrm{~h}$ (starch and pectin) and $48 \mathrm{~h}$ (CMC) in $100 \mathrm{ml}$ serum bottles, closed with butyl rubber stoppers. All measurements were done in triplicates.

Analyses

The $\mathrm{pH}$ of the incubation medium was measured at the beginning and at the end of incubation. Production of SCFA and their molar ratio were determined by gas chromatography on a column with Chromaton N-AW with $10 \% \mathrm{SP} 1200$ and $1 \% \mathrm{H}_{3} \mathrm{PO}_{4}$. Length of the column was $1.8 \mathrm{~m}$. The separation was carried out at $130{ }^{\circ} \mathrm{C}$ with nitrogen $(150 \mathrm{kPa})$ as carrier gas and FID. Ammonia was determined with Nessler reagent (Kopečný and Bartoš 1990).

Statistical evaluation

The significance of differences between the elevated and restricted groups was evaluated by the Student's $t$-test, all data were subjected to analysis of variance using General Linear Model Procedure (SAS 1985). 
Table 1

Microbial fermentation products in the stool of IBS patients before and after treatment with Hylak Tropfen Forte and in healthy persons

\begin{tabular}{|l|c|c|c|c|c|c|c|c|c|c|}
\hline & & $\mathrm{pH}$ & Total SCFA & Acetate & Propionate & Butyrate & Ammonia & & Ratio & \\
\hline & $\mathrm{n}$ & & & $\mathrm{mmol} / \mathrm{l}$ & $\mathrm{mmol} / \mathrm{l}$ & $\mathrm{mmol} / \mathrm{l}$ & $\mathrm{mmol} / 1$ & $\mathrm{mmol} / \mathrm{l}$ & $\mathrm{Ac} / \mathrm{Pr}$ & $\mathrm{Pr} / \mathrm{But}$ \\
\hline Before & 16 & Mean & 6.55 & 88.15 & 60.16 & 18.06 & 9.93 & 46.95 & 3.33 & 1.82 \\
\hline treatment & & $\mathrm{SE}$ & 0.8 & 51.86 & 31.52 & 11.25 & 5.98 & 25.96 & 1.97 & 1.54 \\
\hline After & 14 & Mean & 6.83 & 100.66 & 75.6 & 18.21 & 6.84 & 46.2 & 4.15 & 2.66 \\
\hline treatment & & $\mathrm{SE}$ & 0.42 & 46.19 & 37.87 & 8.25 & 3.41 & 25.75 & 0.85 & 1.11 \\
\hline Control & 5 & Mean & 6.88 & 108.95 & 73.26 & 26.08 & 9.16 & 44.02 & 2.81 & 2.84 \\
\hline & & $\mathrm{SE}$ & 0.34 & 26.84 & 19.99 & 6.05 & 2.21 & 27.23 & 1.13 & 1.02 \\
\hline
\end{tabular}

A: Number of samples

Ac: Acetate

Pr: Propionate

But: Butyrate

SCFA: Short chain fatty acids

\section{Results}

All experiments were designed for three groups of stool donors. Healthy individuals represented Control group. Another group was formed by patients with irritable bowel syndrome (IBS) diagnosis. The third set of donors was represented by IBS patients treated with Hylak Tropfen Forte.

Microbial fermentation products in the colon

Concentration of SCFA, ammonia and $\mathrm{pH}$ were determined in faeces of all three groups (Table 1). Values of $\mathrm{pH}$ were non-significantly higher in control and set of samples obtained after treatment by Hylak Tropfen Forte. This shift did not correlate with SCFA levels. Patients with irritable bowel syndrome showed lower concentrations of total SCFA. This change was caused mainly by lower levels of acetate and partly propionate. On the other hand, butyrate concentration was highest in IBS patients. The treatment with Hylak Tropfen Forte decreased the concentration of butyrate produced by colonic bacteria. Due to great variation of obtained values all differences were non-significant. The ratio of acetate to

Table 2

Bacterial counts (CFU) in faeces of IBS patients and healthy control group

\begin{tabular}{|c|c|c|c|}
\hline \multirow{4}{*}{ Group of Bacteria } & \multicolumn{2}{|c|}{ Hylak - forte treatment } & \multirow{2}{*}{ Control } \\
\hline & Before & After & \\
\hline & \multicolumn{2}{|c|}{ Log of Counts $(\mathrm{CFU}) / \mathrm{g}$} & \\
\hline & Mean & Mean & Mean \\
\hline Pectinolytic & 9.656 & 10.935 & 10.752 \\
\hline Sulphate reducing & $9.086^{\mathrm{a}}$ & $7.724^{\mathrm{b}}$ & $6.980^{c}$ \\
\hline Proteolytic & 9.667 & 10.972 & 9.055 \\
\hline Lactate utilizing & 9.121 & 9.853 & 9.021 \\
\hline Lipolytic & $9.520^{\mathrm{a}}$ & $10.750^{\mathrm{b}}$ & $10.253^{\mathrm{b}}$ \\
\hline Cellulolytic & $5.685^{\mathrm{a}}$ & $8.391^{\mathrm{b}}$ & $8.969^{b}$ \\
\hline SS Agar & $9.314^{\mathrm{a}}$ & $5.954^{\mathrm{b}}$ & $5.556^{\mathrm{b}}$ \\
\hline PSAB agar & $10.179^{\mathrm{a}}$ & $6.668^{\mathrm{b}}$ & $6.123^{b}$ \\
\hline Total counts of Anaerobes & 10.176 & 10.779 & 10.685 \\
\hline
\end{tabular}

CFU was determined in seven patients with IBS diagnosis before and after 10 days of Hylak-forte treatment.

Values in rows which do not have the same lower case superscript $(a, b, c)$ differ significantly $(P<0.010)$ 


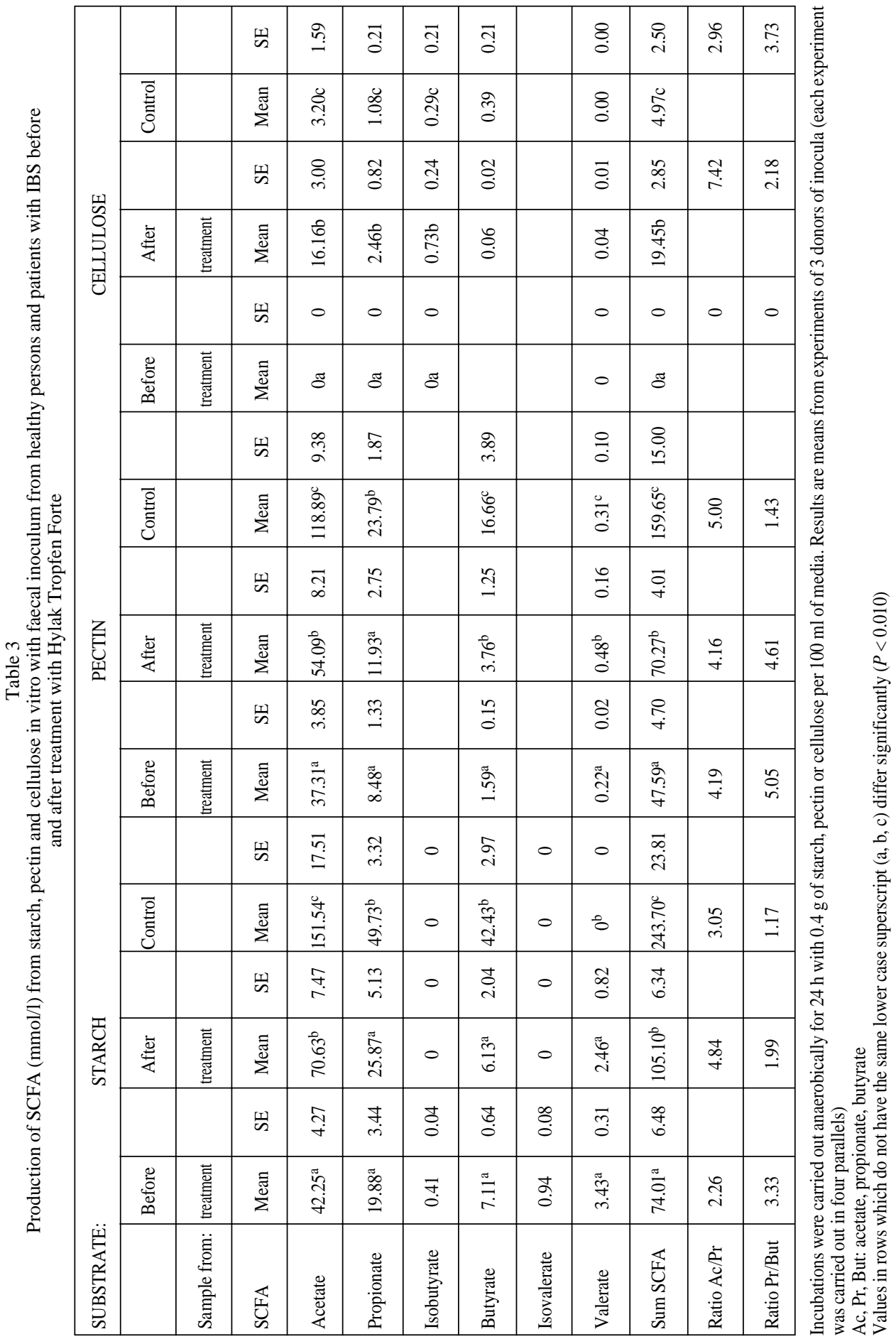


propionate was increased in Hylak Tropfen Forte-treated patients and moved far from the value obtained in control group. On the contrary, ratio of propionate to butyrate in set of Hylak Tropfen Forte-treated individuals was moved to normal levels. Ammonia concentrations were very similar in all sets of samples.

Counts of bacteria in the colon

Numbers of bacteria belonging to selected groups were in the range $10^{4}-10^{11} \mathrm{CFU}$ per gram of faeces (Table 2). Total counts of anaerobic bacteria were similar in all three groups tested. Facultative anaerobes grown on both SS and PSAB agars were significantly higher in samples from IBS patients. Their numbers after Hylak Tropfen Forte treatment decreased by 3 orders to the level observed in control group.

Non-significant lower bacterial counts in IBS patients were observed for pectinolytic bacteria. On the other hand, non-significantly higher CFU in IBS patients were observed for proteolytic and lactate utilizing strains. Significant differences in bacterial counts were found in three groups of bacteria: CFU of sulphate-reducing strains were higher by two orders of magnitude and CFU of cellulolytic and lipolytic strains were decreased in IBS patients. These results indicated a different type of microbial fermentation in tested groups. In general, fibrolytic bacterial population was probably replaced by proteolytic and sulphate reducing bacteria.

The effect of Hylak Tropfen Forte-forte on microbial fermentation

Faecal bacteria from all three groups of donors were tested for their ability to degrade different substrates in vitro. The growth substrates starch, pectin and carboxymethylcellulose were inoculated with faecal homogenates and incubated for 24 or $48 \mathrm{~h}$. After incubation the products of fermentation were measured (Table 3). Degradation of starch by faecal bacteria was significantly depressed in IBS patients, and lower concentrations of acetate, propionate and butyrate were found. Hylak Tropfen Forte treatment partly restored bacterial activity but it did not reach the level observed in the control group.

Pectin degradation in vitro followed a similar pattern. Faecal bacteria of IBS patients showed the lowest ability to degrade pectin. Treatment with Hylak Tropfen Forte increased the acetate production but not to the level of the control group. In comparison with starch, SCFA production was lower indicating lower pectinolytic activity in faeces in general.

There was no evidence of carboxymethylcellulose degradation in vitro by faecal bacteria in IBS patients. The increasing SCFA production in Hylak Tropfen Forte-treated group suggests increased ability of bacteria to degrade cellulose.

\section{Discussion}

The physiological effects of dietary fibre in humans are influenced by physical properties of the fibre and by its degradability in the colon (Bourquin et al. 1992). Fermentation products of the process stimulate epithelial proliferation (Sakata 1987) and high fibre consumption can reduce risk of colon cancer (Trock et al. 1990).

No significantly lower levels of total SCFA, acetate and propionate characterized the faecal SCFA profile of IBS patients compared to the control group. Higher butyrate concentration was observed in samples of our IBS patients. Similar results and trends were described in patients suffering from diarrhoea-predominant IBS (Treem et al. 1996). The SCFA production was partly restored by prebiotic preparation Hylak Tropfen Forte (cellfree fermentation products of Lactobacillus helveticus and gut symbionts) similarly to probiotic treatment with Lactobacillus plantarum (Nobaek et al. 2000). Pro- and prebiotic treatment of IBS is expected to become an integral part of reestablishment of gut microflora (Steer et al. 2000). The health bonuses of such approaches offer the potential to manage many gut disorders prophylactically. 
Bacterial degradation of cellulose in human gastrointestinal tract varies in some extent and it is usually higher in adults (Kelleher et al. 1984). Pectinolytic bacteria in the stool achieve high numbers and they are not so sensitive to environmental changes as the cellulolytic species (Jensen and Canale-Parola 1986).

In our experiments faecal bacteria of IBS patients exerted none or decreased capability to hydrolyze cellulose and pectin. This finding correlated with the total counts of cellulolytic and pectinolytic bacteria. So far no connection of cellulolysis to IBS was indicated.

The Hylak Tropfen Forte-forte had not only an effect on cellulolytic bacteria in the lumen but did influence other groups of microbes. This prebiotic preparation can modify or alter microbial fermentation in the colon of IBS patients.

There are no diagnostic markers for IBS (Borum 2001). It is possible to propose the estimation of cellulolytic bacteria counts and faecal cellulolytic activity as a possible preindication of the irritable bowel syndrome.

\section{Celulolytické bakterie v tlustém střevě člověk a ayndrom dráždivého tračníku}

Syndrom dráždivého tračníku (IBS) představuje jednu ze tř́i hlavních forem chronického zánětu střevní sliznice. Předmětem této studie bylo sledování složení a metabolismus mikroflóry tráveniny u IBS pacientů ve srovnání se zdravými jedinci. Pozorování bylo prováděno u tří skupin donorů stolice: zdravých jedinců, pacientů s diagnostikovaným IBS před a po aplikaci prebiotického preparátu Hylak Tropfen Forte.

Fekální profil těkavých mastných kyselin (TMK) u IBS pacientů byl charakterizován nižší koncentrací celkových TMK, acetátu a propionátu $(88,15 ; 60,16$ a 18,06 mmol/1) a vyšší hladinou butyrátu $(9,93 \mathrm{mmol} / \mathrm{l})$. Pop aplikaci Hylaku Tropfen Forte se celková koncentrace TMK, acetátu a propionátu zvýšila (100,66; 75,60 a 18,21 mmol/l). Koncentrace butyrátu se snížila $(6,84 \mathrm{mmol} / \mathrm{l})$. Koncentrace celkových TMK, acetátu, propionátu a butyrátu byla následující: 108,95; 73,26; 26,08 a 9,16 mmol/l.

Složení bakteriální populace u pacientů s indikovaným IBS vykazovalo zásední změny. Byl pozorován signifikantní nárůst fakultativních anaerobů $(P<0.01)$ a sulfát redukujících bakterií $(P<0.01)$. Statisticky významný byl pokles počtů celulolytických $(P<0.01)$ a lipolytických bakterií. Celkové počty pektinolytických, proteolytických a laktát utilizujících bakterií nevykazovaly signifikantní změny. Po aplikaci preparátu Hylak Tropfen Forte se signifikantně zvýšily počty celulolytických bakterií a naopak snížily počty fakultativních anaerobů a sulfát redukujících bakterií.

U fekální směsné populace bakterií získané od všech tří skupin donorů byla sledována schopnost rozkládat celulosu, pektin a škrob. Rozklad škrobu a pektinu byl u IBS pacientů výrazně snížen. Degradace celulosy však nebyla vůbec pozorována. Po aplikaci preparátu Hylak Tropfen Forte se všechny tři hydrolytické aktivity zvýšily, ale nedosáhly hodnot pozorovaných v kontrolní skupině.

\section{Acknowledgements}

This work was supported by The Grant Agency of the Czech Republic (Project No. 525/02/0402).

\section{References}

BORUM, ML 2001: Irritable bowel syndrome. Primary Care 28: 523-530

BOURQUIN, LD, TITGEMEYER, EC, GARLEB, KA, FAHEY, GC 1992: Short- chain fatty acid production and fiber degradation by human colonic bacteria: Effects of substrate and cell wall fractionation procedures. J Nutr 122: $1508-1520$

BRYANT, MP, BURKEY, LA 1953: Cultural methods and some characteristics of some of the more numerous groups of bacteria in the bovine rumen. J Dairy Sci 36: 205- 217

CAMILLERI, M, PRATHER, CM 1992: The irritable bowel syndrome: Mechanisms and a practical approach to management. Ann Int Medicine 116: 1001-1008 
JENSEN, NS, CANALE-PAROLA, E 1986: Bacteroides pectinolyticus sp. nov. and Bacteroides galactouronicus sp. nov.: Two pectinolytic bacteria from the human intestinal tract. Appl Environ Microbiol 52: 880-887

KELLEHER, J, WALTERS, MP, SKRINIVASA, TR, HART, G, FINDLAY, JM, LOSOWSKI, MS 1984: Degradation of cellulose within the gastrointestinal tract in man. Gut 25: 811-815

KING, TS, ELIA, M, HUNTER, JO 1998: Abnormal colonic fermentation in irritable bowel syndrome. Lancet 352: $1187-1189$

KOPEČNÝ, J, BARTOŠ, S 1990: Activity of hydrolases in the gastrointestinal tract of goats. Small Ruminant Res. 3: $25-35$

KOPEČNÝ, J, MAROUNEK, M, BARTOŠ, S 1981: Bath-cultures of rumen microorganisms in vitro. Acta Vet Brno 50: $157-178$

NOBAEK, S, JOHANSSON, ML, MOLIN, G, AHRNE, S, JEPPSSON, B 2000: Alteration of intestinal microflora is associated with reduction of abdominal bloating a pain in patients with irritable bowel syndrome. Am J Gastroenterol 95: 1231-1238

ROEDIGER, WEW 1980: The colonic epithelium in ulcerative colitis: An energy-deficiency disease? Lancet 2 : $712-715$

SAKATA, T 1987: Stimulatory effect of short-chain fatty acids on epithelial proliferation in the

rat intestine: possible explanation for the trophic effects of fermentable fiber, gut microbes and luminal trophic factors. Br J Nutr 58: 95-103

SAS User's Guide, 1985. Statistics, 5 ed., SAS Institute, Inc., Cary, NC.

SCHEPPACH, W, SOMMER, H, KIRCHNER, T, PAGANELLI, G-M, BARTRAM, P, CHRISTL, S, RICHTER, F, DUSEL, G, KASPER, H 1992: Effect of butyrate enemas on the colonic mucosa in distal ulcerative colitis. Gastroenterology 103: 51-56

STEER, T, CARPENTER, H, TUOHY, K, GIBSON, GR 2000: Perspectives on the role of the human gut micribiota and its modulation by pro- and prebiotics. Nutr Res Rev 13: 229-254

TEATHER, RM, WOOD, PJ 1982: Use of Congo red-polysaccharide interactions in enumeration and characterization of cellulolytic bacteria from the bovine rumen. Appl Environ Microbiol 43: 777-780

TREEM, WR, AHSAN, N, KASTOFF, G, HYAMS, JS 1996: Faecal short-chain fatty acids in patients with diarrhea-predominant irritable bowel syndrome: In vitro studies of carbohydrate fermentation. J Pediatr Gastroenterol Nutr 23: 280-286

TROCK, B, LANZA, E, GREENWALD, P 1990: Dietary fiber, vegetables and colon cancer: Critical review and meta-analyses of the epidemiologic evidence. J Natl Cancer Inst 82: 650-661 